\title{
Business Development Models in the System of the Russian Electronic Entrepreneurship
}

\author{
Khisaeva A.I. Shaykhutdinova G.F.* Ishmukhametov E.M. \\ Ufa State Petroleum Technological University, Ufa, 450064, Russia \\ "Corresponding author. Email: gula_sh@mail.ru
}

\begin{abstract}
This article discusses the features of business development in the Russian e-business system. The studies analyzed the most progressive business models in which the largest number of Russian entrepreneurs and investors currently operate. Comparative characteristics of business models and the commercial sector. Thus, the mobilization of electronic commerce is an urgent trend in the development of the Russian sector of small and medium-sized businesses in the global network. Along with this, the promising areas of Internet entrepreneurship include: personalization of proposals, regardless of the business model and the number of participants in online commercial interactions (the customer focus of small and medium-sized firms contributes to the development of long-term relationships with government bodies, large companies, and private sector clients); omnichannel business system (SMEs are actively developing several channels for promoting and marketing products, including online and offline platforms); improving the security of trade transactions (a significant proportion of Russians mistrust electronic transactions due to the presence of fraudulent transactions in the electronic digital environment); use of innovative electronic marketing tools (the trend of 2020 is the publication of advertising messages through blogging, streaming services, podcasts, electronic publications, etc.). The considered business models in the Russian e-business system have great potential, and further development of electronic-digital management will be aimed at their qualitative improvement. The interaction of representatives of small, medium and large businesses, as well as government bodies, within the framework of various electronic models, can create the conditions for creating a stable and high-tech national economy.
\end{abstract}

Keywords: e-commerce, entrepreneurship, small and medium-sized businesses, $B 2 C, C 2 C, B 2 B, B 2 G, e$ -

business, business models

\section{INTRODUCTION}

Currently, e-business is gaining high growth rates in the economies of developed and developing countries. Business leaders strive to digitalize all stages of their own private economy in order to increase competitiveness, reduce time and financial costs, and expand the consumer audience. The emergence of an increasing number of entrepreneurs in the e-commerce market has led to the development of e-business classification. So, in modern theory and practice, all subjects of this market are typified by several signs:

- for the purpose of organizing a business (partial use of Internet resources as part of the development of a traditional form of economic activity; creating a business on the Internet using complex web tools);

- by the method of electronization (the use of computer and desktop devices for business development in the global network; the use of exclusively mobile devices);

- according to the functional purpose (information and communication trading, financial and banking, advertising projects) [1];

- by the method of organizing Internet business (selfdevelopment of projects by entrepreneurs; development and implementation of business plans by involved specialists);

- on the use of software (use of network services; use of own servers);

- by type of economic relations (table 1). 
Table 1 Business models in the e-business system

\begin{tabular}{|c|c|c|c|}
\hline & Business man & Consumer & State \\
\hline Business man & $\begin{array}{l}\text { B2B - the development of } \\
\text { economic interaction } \\
\text { between commercial } \\
\text { organizations: } \\
\text { medium and large firms. } \\
\text { Examples: Alibaba Group, } \\
\text { Avant Group, TIU.ru, } \\
\text { Brandson, Clickky, PAOK } \\
\text { Rosneft, Intel, etc. }\end{array}$ & \begin{tabular}{l}
\multicolumn{1}{c}{ B2C - the } \\
development of commercial \\
relationships \\
consumers and entrepreneurs \\
on the Internet. \\
Examples: \\
AliExpress, Booking.com, \\
Amazon, Otto Group, QIWI, \\
Dell, Ikea, Inditex, Wal-Mart, \\
Starbucks Corporation, \\
Hennes \& Mauritz, etc.
\end{tabular} & $\begin{array}{l}\text { B2G - the } \\
\text { development of economic and } \\
\text { social interaction between a } \\
\text { commercial organization and } \\
\text { the state. } \\
\text { In Russia, the portal } \\
\text { of the unified procurement } \\
\text { information system } \\
\text { Zakupki.gov.ru operates. }\end{array}$ \\
\hline Consumer & $\begin{array}{l}\text { C2B - the development of } \\
\text { commercial relationships } \\
\text { between consumers and } \\
\text { entrepreneurs, where the } \\
\text { consumer has a direct impact } \\
\text { on the company, } \\
\text { independently setting the } \\
\text { cost of products. } \\
\text { Examples: Priceline.com, } \\
\text { Expedia Inc. }\end{array}$ & \begin{tabular}{l}
\multicolumn{1}{c}{ C2C - the } \\
development of economic \\
interaction between consumers \\
who are not business people. \\
Examples: \\
BlaBlaCar, DogVacay, Avito, \\
EBay, VK.com, Youla.rg, \\
IRR.ru, \\
Couchsurfing, \\
SkillShare, etc.
\end{tabular} & $\begin{array}{l}\text { C2G- development } \\
\text { of information interaction } \\
\text { between non-commercial } \\
\text { entities (societies, individuals) } \\
\text { and the state with the goal of } \\
\text { creating a public resonance } \\
\text { around a significant social and } \\
\text { / or economic problem. }\end{array}$ \\
\hline State & $\begin{array}{l}\text { G2B - the development of } \\
\text { economic and social } \\
\text { interaction } \\
\text { commercial organizations } \\
\text { and the state with the aim of } \\
\text { supporting and developing } \\
\text { the business. } \\
\text { Examples: G2b.tatar.ru, } \\
\text { G2b.perm.ru, auctions of the } \\
\text { United States General } \\
\text { Services Office (GSA), } \\
\text { Buyers.gov, etc. }\end{array}$ & $\begin{array}{l}\text { G2C }- \text { the } \\
\text { development of social and } \\
\text { economic relations between } \\
\text { the state and citizens on the } \\
\text { Internet. } \\
\text { Examples: } \\
\text { Trudvsem.ru, Gosuslugi.ru, } \\
\text { Edu.ru, Rosreestr.ru, E- } \\
\text { government, Bitnation, } \\
\text { Electronic Public Services, } \\
\text { Doingbusiness.org etc. }\end{array}$ & $\begin{array}{l}\text { G2G - } \text { socio- } \\
\text { economic interaction between } \\
\text { government agencies and } \\
\text { individual states. This model } \\
\text { involves transactions between } \\
\text { government departments, } \\
\text { ministries, agencies, } \\
\text { administrations. }\end{array}$ \\
\hline
\end{tabular}
(C2C) and Business-to-Government (B2G) [2]. First of all,
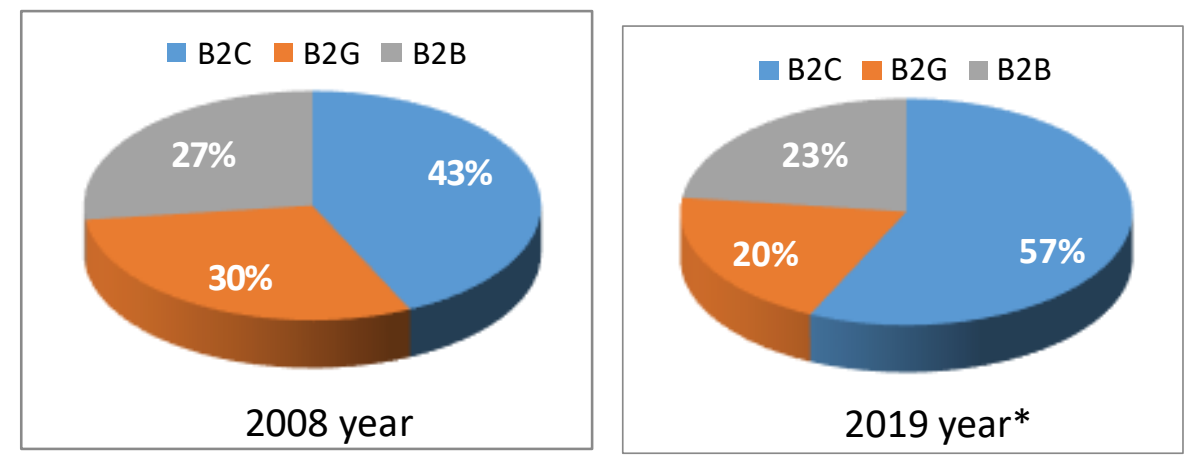

* according to preliminary data

Figure 1 The structure of the Russian e-commerce market [3] 
As can be seen from Figure 1, a large share in the structure of the Russian e-commerce market (taking into account exclusively business models based on the participation of private business executives in the SME sector and large companies) in the B2C segment. The effectiveness of the development of small or medium-sized businesses in this sector is due to the presence of a huge number of electronic-digital technologies available to private entrepreneurs regardless of their financial condition. Most technologies are used free of charge: social and streaming networks, media advertising, contextual product promotion, etc. In addition, Russian entrepreneurs, when organizing their own business, prefer to follow the omnichannel principle, developing simultaneously online and offline sales points. In other words, the growth of the B2C segment is ensured by the emergence of both Internet-oriented firms and traditional-format trading companies seeking to increase sales using current Internet technologies in a partial or full presentation. The features of the Russian B2C market include:

- presence of high competition between entrepreneurs in the SME sector: the more online channels a company uses to sell products, the greater its level of competitiveness; - assortment of goods and services offered on the electronic market is quite diverse, but the pricing policy of Russian firms is still inferior to the pricing and assortment policies of Chinese manufacturers (in this regard, some price categories on the Russian electronic market are completely absent, since there are foreign substitutes for more low prices and guaranteed free delivery);

- both sales specialists and manufacturers, individual entrepreneurs without experience and special skills in trading can act as sellers;

- about $76 \%$ of entrepreneurs from the total number of online sellers use social channels, which bring $40 \%$ of all income from electronic commerce;

- 2019 The trend of 2019 and 2020 in Russia was the formation of online business through mobile applications and, in particular, through messengers: $74 \%$ of entrepreneurs using this channel increased sales by $15-20$ $\%$.

Another popular business model in the Russian ecommerce market is the B2B segment. This type of interaction among the participants in the global network involves the integration of small, medium and large businesses in a single electronic digital space, which for small firms creates reliable links with larger companies (private owners use the products of large organizations, provide them with their own services), and for large ones they form potential partnership with small but highly specialized firms (large organizations, working with the SME sector, reduce their own financial and time costs). The business platform under consideration is significantly inferior in development to the Russian B2C and C2C segments. But an even greater gap between the segments is observed in the context of developed and developing countries (Figure 2).

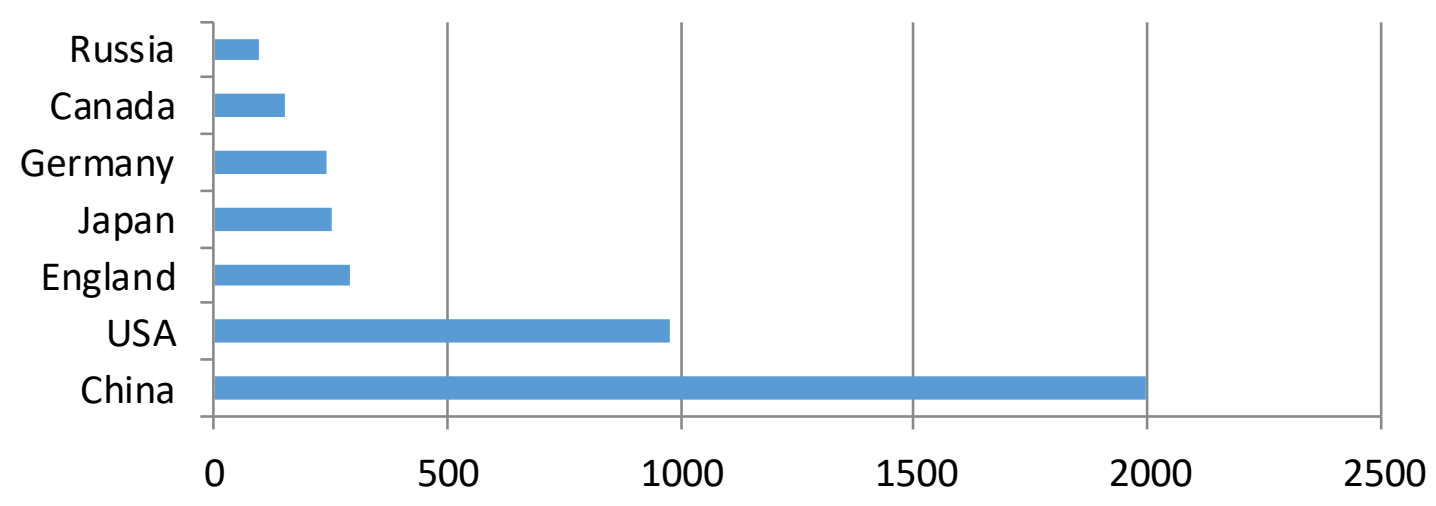

Figure 2 Volumes of B2B markets in Russia and foreign countries at the beginning of 2019, in billion dollars [4]

The root cause of the lag in the development of the Russian B2B segment from countries such as China, the USA and England is the late formation of the business model itself and Russian e-commerce in general. In addition, the following factors influence low B2B development rates in Russia:

- underdevelopment of specialized software products: lowcost platforms can satisfy the needs of only microenterprises, and programs in the expensive segment are absolutely not available for small, medium, and some large firms. Optimization of existing software products likewise requires significant financial investments that SMEs do not have;

- "personnel shortage" - the lack of qualified personnel (managers, programmers, IT specialists) who are able to maintain and adjust online transactions between partner companies and consumer companies in the long term;

- some of the developed B2B platforms do not attract potential customers due to the lack of high-quality functionality, analytics, integrated applications, etc.

All of the above, to one degree or another, inhibits the development of the B2B market and the penetration of "small" entrepreneurs in the structure of the segment. For 
conditions for potential service providers. In addition, $\mathrm{B} 2 \mathrm{G}$ interactions in Russia are characterized by the following features:

- development or stagnation of relations between the state and small and medium-sized businesses is significantly influenced by implicit personal motives of authorities (for example, growth in public service, remuneration, recognition of higher government officials) [5];

- decisions on tendering tendering firms, as a rule, take a long time and are multi-stage in nature (payment for the services of supplier firms is often appointed only after all the conditions of the contract are met);

- among suppliers of goods and services, the largest share is made by trade professionals, experienced entrepreneurs and management specialists;

- the other side of the profitability of public procurement severe penalties in case of failure to meet the deadlines of transactions or poor-quality work of executing firms.

There is a high level of competition among suppliers in this segment.

Summarizing the above, we give a comparative description of e-commerce business models with the participation of small, medium and large enterprises according to key criteria (table 2).

Table2 Comparative characteristics of business models of electronic commerce with the participation of the business sector (compiled from [6])

\begin{tabular}{|c|c|c|c|}
\hline $\begin{array}{c}\text { Comparison } \\
\text { criterion }\end{array}$ & B2C & B2G & B2B \\
\hline Consumers & $\begin{array}{l}\text { Individuals who do not } \\
\text { have market power }\end{array}$ & Government departments & $\begin{array}{l}\text { Small, medium and large } \\
\text { firms }\end{array}$ \\
\hline Sellers & $\begin{array}{l}\text { Large, medium and small } \\
\text { firms (including micro- } \\
\text { enterprises and individual } \\
\text { entrepreneurs) }\end{array}$ & $\begin{array}{l}\text { Large, medium and small } \\
\text { firms (including } \\
\text { entrepreneurs) }\end{array}$ & Large and medium-sized firms \\
\hline $\begin{array}{l}\text { Market Demand } \\
\text { for Innovation }\end{array}$ & High & Low or medium & High or medium \\
\hline Primary goal & End user satisfaction & $\begin{array}{l}\text { Effective implementation of } \\
\text { government requests }\end{array}$ & Customer satisfaction \\
\hline Transaction & Subjective, arbitrary & Multi-stage, formalized & Systematized \\
\hline $\begin{array}{c}\text { Consumption } \\
\text { motivation }\end{array}$ & Desire to purchase goods & $\begin{array}{c}\text { Implementation of the state } \\
\text { program }\end{array}$ & $\begin{array}{c}\text { Solving corporate problems of } \\
\text { the company }\end{array}$ \\
\hline Source of offer & Seller, consumer & Government departments & Seller, consumer \\
\hline $\begin{array}{c}\text { Level of } \\
\text { professionalism }\end{array}$ & Average & High & Medium or high \\
\hline $\begin{array}{c}\text { Territorial } \\
\text { attachment of } \\
\text { subjects }\end{array}$ & None (doesn't matter) & Matters to suppliers & $\begin{array}{c}\text { An important but not } \\
\text { necessary condition for the } \\
\text { transaction }\end{array}$ \\
\hline $\begin{array}{c}\text { Electronic } \\
\text { Interaction Tools }\end{array}$ & $\begin{array}{c}\text { Social and streaming } \\
\text { networks, online stores, } \\
\text { online auctions, } \\
\text { marketplaces, official web } \\
\text { pages, instant messengers. }\end{array}$ & $\begin{array}{l}\text { Official regional public } \\
\text { procurement sites, Unified } \\
\text { public procurement system, } \\
\text { municipal PPP sites. }\end{array}$ & $\begin{array}{l}\text { Marketplaces, official sites, } \\
\text { other electronic trading } \\
\text { platforms, EDI technologies, } \\
\text { extranet systems, online } \\
\text { auctions. }\end{array}$ \\
\hline
\end{tabular}




\section{RESEARCH METHODOLOGY}

A completely different form of economic interaction in the e-commerce market is the $\mathrm{C} 2 \mathrm{C}$ segment. Despite the fact that sellers in this electronic trading direction are not legally registered individual entrepreneurs and do not form enterprises, their role in the Russian market is great. About 8 million sellers (non legal entities) and 10 million consumers are involved in this segment in Russia. In 2019, the market volume based on the sale and exchange of products between private individuals amounted to 90 million rubles [7]. Exceptional features of the Russian C2C segment are:

- of the total number of sellers, only $5 \%$ are sales specialists;

\begin{abstract}
- $92 \%$ of sellers carry out trade transactions in cities of personal residence;

- $63 \%$ of the total volume of goods sold are classified as former use;

- among the consumer consumers of the Consumer-toConsumer market, more than $33 \%$ do not use official online stores, preferring $\mathrm{C} 2 \mathrm{C}$ marketplaces and other electronic platforms;

- more than $31 \%$ of the total number of Russian web users are involved in the $\mathrm{C} 2 \mathrm{C}$ segment;

- the most popular sales channel for products among social sector sellers is social networks (Figure 3).
\end{abstract}

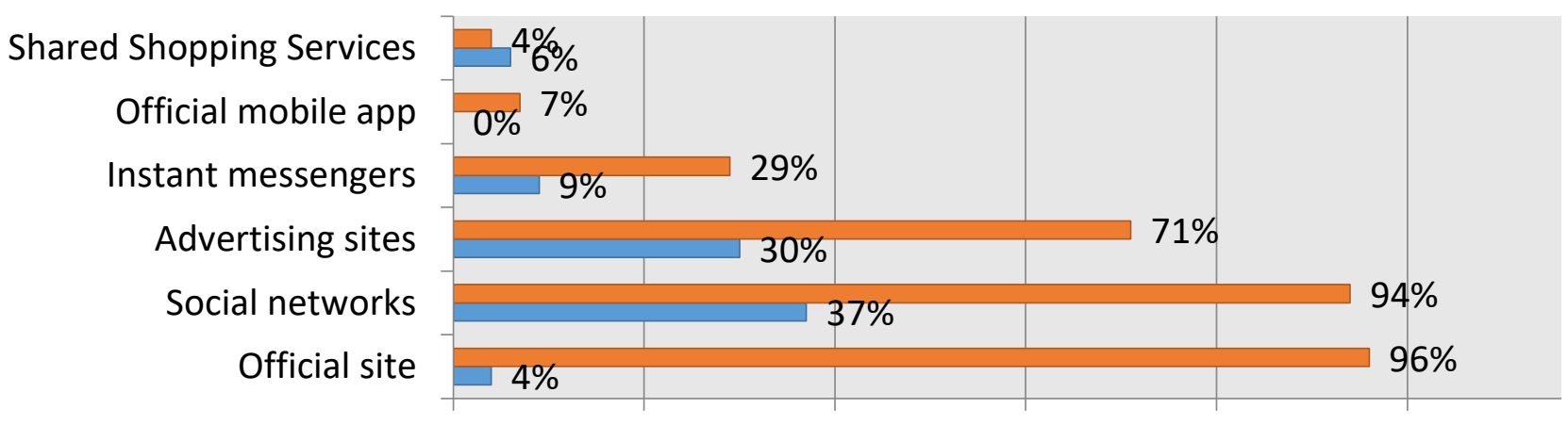

* Percentage of entrepreneurs using social channels;

** percentage of web users who carry out transactions for the sale of products through social channels.

Figure 3 Sales channels in the Russian segments of C2C and B2C

\section{RESEARCH RESULT}

In almost all of the considered segments, entrepreneurs and, in particular, representatives of small and medium- sized businesses, are entering a new level of e-commerce, characterized by the use of exclusively mobile devices instead of the usual computer and desktop devices (Figure 4). 


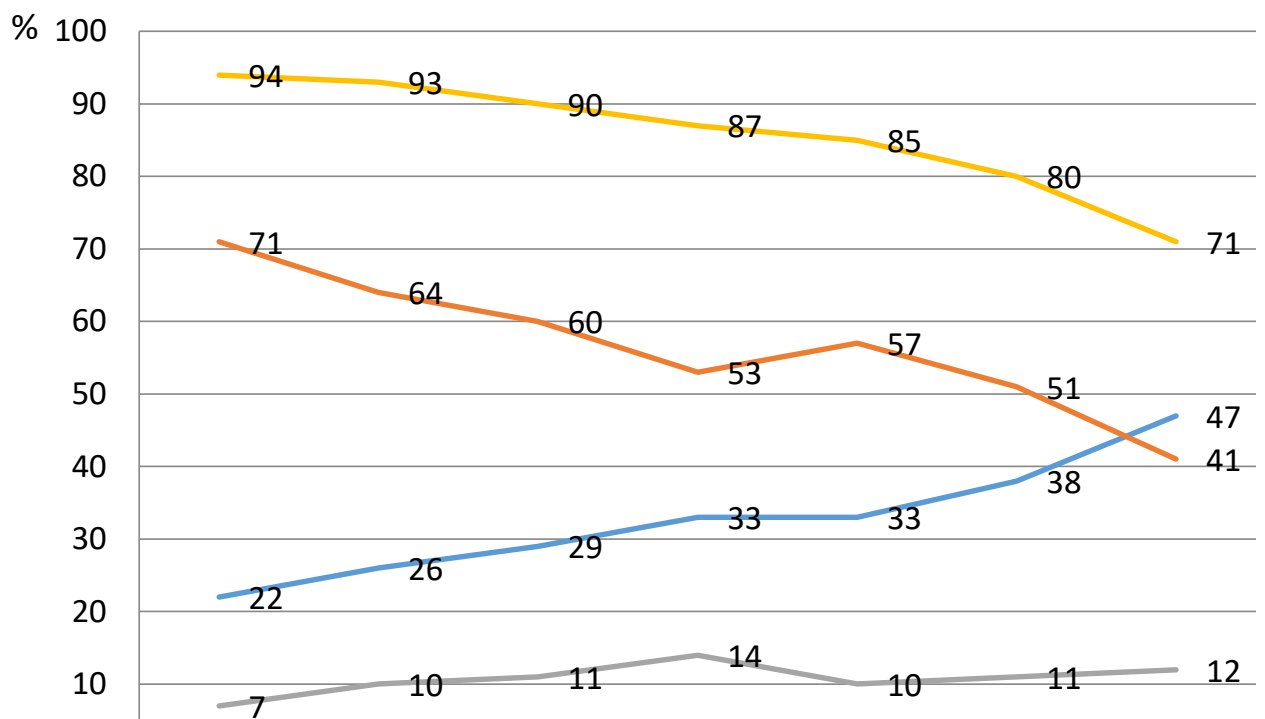

Figure 4 Dynamics of online shopping from various devices in Russia for 2019 [8]

\section{DISCUSSION OF RESULTS}

The priority development of $\mathrm{B} 2 \mathrm{C}, \mathrm{B} 2 \mathrm{~B}, \mathrm{~B} 2 \mathrm{G}$ and $\mathrm{C} 2 \mathrm{C}$ segments in the mobile environment is due primarily to the fact that consumers of all business models have the opportunity to personalize and speed up their purchases. In addition, mobile devices provide faster payment transactions, high maneuverability of Internet users in various Internet systems, and reduction of time costs associated with the search and selection of necessary products.

\section{CONCLUSION}

Thus, the mobilization of electronic commerce is an urgent trend in the development of the Russian sector of small and medium-sized businesses in the global network. Along with this, the promising areas of Internet entrepreneurship include:

- personalization of proposals, regardless of the business model and the number of participants in online commercial interactions (the customer focus of small and medium-sized firms contributes to the development of long-term relationships with government bodies, large companies, and private sector clients);

- omnichannel business system (SMEs are actively developing several channels for promoting and marketing products, including online and offline platforms);

- improving the security of trade transactions (a significant proportion of Russians mistrust electronic transactions due to the presence of fraudulent transactions in the electronic digital environment);
- use of innovative electronic marketing tools (the trend of 2020 is the publication of advertising messages through blogging, streaming services, podcasts, electronic publications, etc.).

The considered business models in the Russian e-business system have great potential, and further development of electronic-digital management will be aimed at their qualitative improvement. The interaction of representatives of small, medium and large businesses, as well as government bodies, within the framework of various electronic models, can create the conditions for creating a stable and high-tech national economy.

\section{REFERENCES}

[1] Chernoivanov A.P. Directions for the development of electronic entrepreneurship in modern Russia // Socio-economic phenomena and processes. 2011. No. 10. Pp. 221 - 227.

[2] Gaysina R.R., Grishin K.E. The use of innovative ecommerce technologies in entrepreneurship // Actual problems of modern science. 2018. p. 92 - 98.

[3] Internet trading in Russia: the market "shot" due to the crisis // [Electronic resource] URL: https://safe.cnews.ru/reviews/free/2009/articles/articles 24.shtml (accessed date: 13.02 .2020).

[4] Why does wholesale online trading (B2B) in Russia lag behind the West, China and retail e-commerce // [Electronic resource] URL: https://www.shopolog.ru/metodichka/analytics/pochem 
u-optovaya-onlayn-torgovlya -b2b-v-rossii-otstaet-otzapada-kitaya-i-roznichnoy / (accessed: 02.15.2020).

[5]. Marketing in the B2G market. Features of work // [Electronic resource] URL: https://spravochnick.ru/marketing/potrebitel_v_marketi nge/marketing_na_rynke_b2g_osobennosti_raboty// (accessed date: 02/18/2020).

[6] Avramenko S. A., Sekerin V. D. B2G Market: Essence and Statistical Analysis // News of MSTU. 2013. No4 (18). S. 134-141.

[7] The Russian online trading market // [Electronic resource] URL: https://adindex.ru/specprojects/market6/commerce/index.phtml (accessed: 02.19.2020).

[8] Internet statistics 2019: traffic, sites and blogs, domains, social media, online advertising and ecommerce // [Electronic resource] URL: https://sdvv.ru/ (accessed: 02.22.2020). [9] Shaykhutdinova G.F., Nikonova S.A., Karachurina R.F., Sharipova I.M., Korotkova L.N., Sultanova L.F. Stimulating of entrepreneurs' innovative activity in the republic of Bashkortostan // Journal of Fundamental and Applied Sciences. 2017. T. 9. № 7S. C. 1005-1015.

[10] Zakirova I.R., Zainasheva Z.G., Shaikhutdinova G.F., Ibragimova N.U., Korotkova L.N., Mukhametova D.D A modern approach to comprehensive competitive potential assessment for service providers // International Journal of Engineering and Technology(UAE). 2018. T. 7. № 4.36. C.209-212. 